\title{
Accuracy and Applicability of Resting Metabolic Rate Prediction Equations Differ for Women Across the Lifespan
}

\author{
Kathleen Woolf ${ }^{1, *}$, Shirley Miller ${ }^{2}$, Christine Reese $^{3}$, Leah Beaird ${ }^{4}$ and Maureen Mason ${ }^{4}$ \\ ${ }^{1}$ New York University, Steinhardt School of Culture, Education, and Human Development, Department of \\ Nutrition, Food Studies, and Public Health, 411 Lafayette Street, $5^{\text {th }}$ Floor, New York, NY 10003-7035, USA \\ ${ }^{2}$ New York University Langone Medical Center, Hospital for Joint Diseases, 301 East $17^{\text {th }}$ Street, New York, \\ NY 10003-3804, USA \\ ${ }^{3}$ Phoenix College, Applied Technology, Family and Consumer Sciences Department, 1202 West Thomas \\ Road, Phoenix, AZ 85013-4208, USA \\ ${ }^{4}$ Arizona State University, School of Nutrition \& Health Promotion, 550 North $3^{\text {rd }}$ Street, Phoenix, AZ 85004- \\ 0698, USA
}

Abstract: Background: Nutrition clinicians need accurate and reliable resting metabolic rate (RMR) assessments to determine energy needs and an appropriate nutrition care plan.

Material/Methods: This cross-sectional study compared the accuracy of eight RMR prediction equations (HarrisBenedict, Robertson and Reid, Cunningham 1980, FAO/WHO/UNU, Owen, Mifflin-St. Jeor, Cunningham 1991, and Nelson) to measured RMR by indirect calorimetry among young $(n=57$; age: $25 \pm 3$ years), midlife ( $n=57$; age: $44 \pm 3$ years), and older ( $n=46$; age: $68 \pm 5$ years) women. Paired $t$-tests examined differences between predicted and measured RMR. Statistical analyses were conducted using SPSS (version 21), with significance defined as $p<0.05$. Bland-Altman plots displayed prediction bias and agreement. Prediction accuracy was defined when predicted RMR was $\pm 10 \%$ of measured RMR. Serum thyroid stimulating hormone and follicle stimulating hormone concentrations were measured to assess thyroid function and ovarian reserve, respectively.

Results: The difference between predicted and measured RMR ranged from $+0.6 \%$ (Owen) to $+17.7 \%$ (Cunningham 1980 ) for the young, $-2.8 \%$ (Nelson) to $+18.1 \%$ (Cunningham 1980 ) midlife, and +2.8 (Nelson) to $+26.7 \%$ (Cunningham 1980 ) older women. For the young women, only the Owen equation predicted RMR similar to measured RMR $(p=0.905)$. For the older women, only the Nelson equation predicted RMR similar to measured RMR $(p=0.051)$. All estimates using prediction equations were significantly different from measured values for midlife women.

Conclusion: Many RMR prediction equations have limited applicability for women at difference stages of the lifespan, thus impacting patient outcomes. Additional research is necessary to determine the appropriateness of RMR prediction equations among women of all ages.

Keywords: Resting metabolic rate (RMR), indirect calorimetry, RMR prediction equation, women, lifespan.

Accurate resting metabolic rate (RMR) assessments are necessary for Registered Dietitian Nutritionists and nutrition clinicians to estimate energy requirements and generate an appropriate nutrition care plan. RMR describes the energy required to support physiologic function and maintain body temperature when the body is in a rested and fasted state [1]. Several factors may impact RMR including: age [2,3], body composition [2], weight [3], sex [2,4], heart rate [3], menstrual cycle [5], smoking status [3], and caffeine intake [6]. Because RMR typically represents the largest component of total daily energy expenditure in healthy adults [2], Registered Dietitian Nutritionists and nutrition clinicians need reliable resting metabolic rate (RMR) estimates when determining energy needs for patients [7].

${ }^{*}$ Address correspondence to this author at the Steinhardt School of Culture, Education, and Human Development, Department of Nutrition, Food Studies, and Public Health, New York University, 411 Lafayette Street, 5th Floor, New York, NY 10003-7035, USA; Tel: (212) 992-7898; Fax: (212) 995-4194;

E-mail: kathleen.woolf@nyu.edu
Currently, indirect calorimetry (IC) remains the "gold standard" for metabolic rate measurement [8]. Unfortunately IC is not available in most clinical settings $[9,10]$. Consequently, multiple RMR prediction equations have been developed to estimate total daily energy requirements and are common in both inpatient and outpatient practice (Table 1). However, the characteristics of the participants used to derive the prediction equation may influence the RMR estimate, potentially contributing to over- and underfeeding of patients. Thus, knowledge of the demographics of the original sample may help determine applicability of the prediction equations to different demographic groups (i.e., sex, body weight, race/ethnicity, health status) [7].

Harris and Benedict [11] developed the first RMR prediction equation using height and weight measurements from predominantly young, normalweight participants in the early 1900s. During the 1950s, Robertson and Reid [12] developed an equation 
Table 1: Formulas and Characteristics of Eight Resting Metabolic Rate Prediction Equations for Women

\begin{tabular}{|c|c|c|}
\hline $\begin{array}{l}\text { Prediction } \\
\text { Equation }\end{array}$ & Formula & $\begin{array}{l}\text { Characteristics of Participants in } \\
\text { the Development of the Prediction Equation }\end{array}$ \\
\hline $\begin{array}{l}\text { Harris-Benedict } \\
1919[11]\end{array}$ & $\begin{array}{l}\mathrm{kcal} / \mathrm{day}=655.0955+9.5634 \mathrm{x} \text { weight }(\mathrm{kg})+ \\
1.8496 \mathrm{x} \\
\text { height }(\mathrm{cm})-4.6756 \mathrm{x} \text { age }(\text { years })\end{array}$ & $\begin{array}{l}n=103 \text { women } \\
\text { Age: } \text { mean (range) }=31 \text { years }(15-74 \text { years) } \\
20-30 \text { years }(n=55), 40-50 \text { years }(n=8),>60 \text { years }(n=6) \\
\text { Predominantly normal }- \text { weight women } \\
\text { Weight mean (range) }=56.4 \mathrm{~kg}(35.6-94.1 \mathrm{~kg})\end{array}$ \\
\hline $\begin{array}{l}\text { Robertson and } \\
\text { Reid } \\
1952[12]\end{array}$ & $\mathrm{kcal} / \mathrm{day}=\mathrm{BSA}\left(\mathrm{m}^{2}\right)^{\mathrm{a}} \times 24 \times$ (age specific value $)$ & $\begin{array}{l}\mathrm{n}=1323 \text { women } \\
\text { Female nurses in training at Middlesex Hospital, England, } \\
\text { medical students and other hospital staff, children attending } \\
\text { welfare clinics and on tonsillectomy waiting lists, members of } \\
\text { the public who responded to newspaper appeals } \\
\text { Age }=3-74 \text { years } \\
20-30 \text { years }(n=377), 40-50 \text { years }(n=94),>60 \text { years }(n= \\
35) \\
\text { Weight was not provided }\end{array}$ \\
\hline $\begin{array}{l}\text { Cunningham } \\
1980[19]\end{array}$ & $\mathrm{kcal} / \mathrm{day}=500+22 \mathrm{x}$ lean body mass & 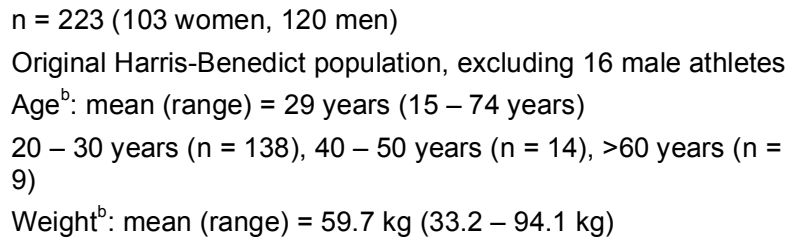 \\
\hline $\begin{array}{l}\text { FAO/WHO/UNU } \\
1985[13]\end{array}$ & $\begin{array}{l}18-30 \text { years: } \mathrm{kcal} / \text { day }=13.3 \times \text { weight }(\mathrm{kg})+334 \mathrm{x} \\
\text { height }(\mathrm{m})+35 \\
30-60 \text { years: } \mathrm{kcal} / \mathrm{day}=8.7 \times \text { weight }(\mathrm{kg})-25 \mathrm{x} \\
\text { height }(\mathrm{m})+865 \\
>60 \text { years: } \mathrm{kcal} / \text { day }=9.2 \times \text { weight }(\mathrm{kg})+637 \mathrm{x} \\
\text { height }(\mathrm{m})-302\end{array}$ & $\begin{array}{l}\mathrm{n}=11,000 \text { men, women, and children } \\
\text { Developed using data from Schofield et al. }[14,15] \\
\text { Healthy individuals of varied age, weight, and height included; } \\
\text { however, limited representation of older adults } \\
\text { Age and weight characteristics not provided }\end{array}$ \\
\hline $\begin{array}{l}\text { Owen et al. } \\
1986[17]\end{array}$ & Nonathletes ${ }^{\mathrm{c}}: \mathrm{kcal} / \mathrm{day}=795+7.18 \times$ weight $(\mathrm{kg})$ & $\begin{array}{l}n=36 \text { women (excluding } 8 \text { athletes) } \\
\text { Age: mean (range) }=36 \text { years }(18-65 \text { years) } \\
20-30 \text { years }(n=14), 40-50 \text { years }(n=3),>60 \text { years }(n=1) \\
\text { Weight: mean (range) }=79 \mathrm{~kg}(43-143 \mathrm{~kg}) \\
\text { Included a wide range of weight categories: underweight }(n= \\
\text { 1), normal weight }(n=15) \text {, overweight }(n=4) \text {, obese }(n=10) \text {, } \\
\text { and extremely obese }(n=6)\end{array}$ \\
\hline $\begin{array}{l}\text { Mifflin-St. Jeor } \\
1990[18]\end{array}$ & $\begin{array}{l}\mathrm{kcal} / \mathrm{day}=9.99 \times \text { weight }(\mathrm{kg})+6.25 \times \text { height }(\mathrm{cm})- \\
4.92 \times \\
\text { age }(\text { years })-161\end{array}$ & $\begin{array}{l}n=247 \text { women } \\
\text { Age mean (range })=44.6 \text { years }(20-76 \text { years }) \\
\text { Weight mean }(\mathrm{range})=70.2 \mathrm{~kg}(46-120 \mathrm{~kg}) \\
\text { Normal weight }(n=135) \text { and obese }(n=112) \\
\text { Detailed age information of individual participants not provided }\end{array}$ \\
\hline $\begin{array}{l}\text { Cunningham } \\
1991[20]\end{array}$ & $\mathrm{kcal} / \mathrm{day}=370+21.6 \times \mathrm{FFM}^{\mathrm{d}}(\mathrm{kg})$ & $\begin{array}{l}\mathrm{n}=1483 \text { men and women } \\
\text { Derived from a compilation of studies published between } 1980 \\
-1989 \\
\text { Detailed age information not provided } \\
\text { Included lean and obese male and female participants }\end{array}$ \\
\hline $\begin{array}{l}\text { Nelson et al. } \\
1992[21]\end{array}$ & $\mathrm{kcal} / \mathrm{day}=25.80 \times \mathrm{FFM}^{\mathrm{d}}(\mathrm{kg})+4.04 \times \mathrm{FM}^{\mathrm{e}}(\mathrm{kg})$ & $\begin{array}{l}n=213 \text { ( } 86 \text { adult men and } 127 \text { adult women) } \\
\text { Derived from a compilation of data sets that included FFM, FM, } \\
\text { and } R E E^{f} \\
\text { Detailed age information not provided } \\
\text { Included non-obese }(n=81) \text { and obese }(n=132) \text { participants }\end{array}$ \\
\hline
\end{tabular}

${ }^{a}$ BSA estimated from stature and body weight by DuBois and DuBois formula [46]: $\mathrm{A}\left(\mathrm{cm}^{2}\right)=\mathrm{W}(\mathrm{kg})^{0.425} \times \mathrm{H}(\mathrm{cm})^{0.725} \times 71.84$.

${ }^{b}$ Calculated from original Harris-Benedict tables (Table C and D) [11].

'Owen et al. published two prediction equations; in the present study the equation for nonathletes was used.

${ }^{\mathrm{d}} \mathrm{FFM}=$ fat free mass

${ }^{\mathrm{e}} \mathrm{FM}=$ fat mass.

${ }^{f} \mathrm{REE}=$ resting energy expenditure. 
that took into account age and sex-specific body surface area to predict metabolic rate. Derivation of the Robertson and Reid equation [12] was based on anthropometric measurements of British children, medical students, hospital employees, and volunteers, representing an age range of more than 70 years. In 1985, the Food and Agricultural Organization/World Health Organization/United Nations University (FAO/WHO/UNU) [13] introduced a series of agespecific RMR prediction equations based on an analysis conducted by Schofield et al. $[14,15]$ that included 114 studies published between 1917 and 1983 , with an international sample of participants. Although this review included a large sample size, the participants were primarily young and midlife men and women, limiting the generalizability $[14,15]$. Conversely, the Owen [16,17] and Mifflin-St. Jeor [18] equations were developed using smaller sample sizes but representing a wide range of ages (18 - 65 years and $20-76$ years, respectively) and body weights (43 - $143 \mathrm{~kg}$ and $46-120 \mathrm{~kg}$, respectively). Similar to the Harris-Benedict [11] and FAO/WHO/UNU [13] equations, the Mifflin-St. Jeor [18] equation calculates RMR using sex, weight, and height as part of the prediction equation.

Given the relationship between lean body mass and RMR, additional equations take into consideration body composition when predicting metabolic rate. The original Cunningham equation (1980) [19] predicts metabolic rate using lean body mass (LBM). The equation [19] was derived using the weight, age, and height values of physically inactive men and women from the original Harris-Benedict study. In 1991, Cunningham revised the equation utilizing a twocompartment model of body composition, fat mass (FM) and fat-free mass (FFM), and expanded the original sample to include men and women with a large range of body weights [20]. Similarly, Nelson et al. [21] combined the datasets of seven studies published from 1982 to 1989 [16,17,22-26], including normal weight, overweight, and obese men and women between the ages of 18-82, to derive an equation that predicts RMR based on FM and FFM.

Because of the importance of accurate energy expenditure estimations, the research literature has examined the applicability of prediction equations within diverse populations [27-33]. Unfortunately, many RMR prediction equations were derived from samples that did not include individuals from all stages of the lifespan. Thus, the applicability of these equations to some age groups is limited [7,30]. For example, validation studies conducted with young adults $[27,28]$ suggest that commonly-used equations, such as the Harris-Benedict and Mifflin-St. Jeor, may not accurately predict RMR in young women. Other studies evaluating the accuracy of RMR prediction have observed that several RMR prediction equations over or underestimate RMR among older adults [29,31-33]. To date, only one published study has investigated the applicability of RMR prediction equations for midlife women [34].

Research is needed to examine the prediction accuracy of current RMR prediction equations on adults throughout the lifespan to identify the most appropriate equation. Therefore, the primary objective of this study was to compare the accuracy of eight RMR prediction equations (Harris-Benedict [11], Robertson and Reid [12], Cunningham 1980 [19], FAO/WHO/UNU [13], Owen [17], Mifflin-St. Jeor [18], Cunningham 1991 [20], and Nelson [21] to measured RMR by IC among a sample of young, midlife, and older women.

\section{METHODS}

\section{Study Design}

This cross-sectional study assessed the accuracy of eight RMR prediction equations to measured RMR. The study visits were completed at Arizona State University (ASU) and the data analysis was completed at New York University (NYU). Both the Human Subjects Institutional Review Board at ASU and the University Committee on Activities Involving Human Subjects (UCAIHS) at NYU approved the study procedures.

\section{Participant Recruitment}

Women $(n=207)$, between the ages of 20-77, were recruited from the Phoenix, Arizona metropolitan area using flyers posted at libraries, churches, college campuses, and community centers. The flyers briefly described the study and invited potential participants to contact the study investigators for more information. Women were eligible for inclusion if they were young (20 - 30 years), midlife ( $40-50$ years), and older ( $\geq 60$ years), at a stable body weight (defined by $<2.2 \mathrm{~kg}$ fluctuation over the past two years), body mass index $(\mathrm{BMI})<30.0 \mathrm{~kg} / \mathrm{m}^{2}$, and nonsmokers. Eligible young and midlife participants needed to report regular menstruation, defined by menstrual cycle duration of approximately 28 days, 12 cycles yearly. Investigators 
excluded women from participating if, at the time of the study, they reported unresolved health conditions, such as diabetes mellitus, cardiovascular disease, cancer, high blood pressure, an eating disorder, or thyroid disease. Researchers determined eligibility over the telephone.

Once preliminary eligibility was established, study investigators invited the potential participants to schedule a research study visit. During the first visit, all participants received detailed information about the study, signed an informed consent form, completed a health history questionnaire, and were interviewed about dietary supplement (vitamin, mineral, herbal) and medication (prescription and over-the-counter) use. At this visit, investigators also provided participants written and verbal instructions for the subsequent study visits that include an RMR measurement, a fasting blood draw, and body composition assessment.

\section{Anthropometry}

Participants completed anthropometric
measurements using a balance beam scale
(HealthOMeter, Sunbeam Products, Boca Raton, FL). Body composition was assessed by dual-energy $\mathrm{x}$-ray absorptiometry using the LUNAR DPX-IQ (GE Healthcare, Madison, WI) instrument.

\section{Biochemical Analysis}

Serum thyroid stimulating hormone (TSH) and follicle stimulating hormone (FSH) concentrations were determined in duplicate by radioimmunoassay from an eight-hour fasting blood sample (MP Biomedicals, Inc, Irvine, CA). Women with a serum TSH concentration exceeding $6.75 \mu \mathrm{IU} / \mathrm{mL}$ were excluded from the study.

\section{Resting Metabolic Rate Measurement and Prediction}

RMR was measured using the Delta Trac II metabolic monitor (Viasys Healthcare, Yorba Linda, $\mathrm{CA}$ ) using the protocol recommended by the Academy of Nutrition and Dietetics Evidence Analysis Working Group [35]. For the young and midlife women, RMR was measured within one week after the onset of menses in order to eliminate the fluctuations in RMR that occur over the course of the menstrual cycle [5]. Investigators calibrated the metabolic cart each morning, prior to the initial RMR measurement, with a gas mixture of oxygen (95\%) and carbon dioxide (5\%). Participants arrived for the RMR measurement after fasting for at least eight hours and abstaining from caffeine [6,36] and physical activity [37] for 24 and 48 hours, respectively. Participants rested in a recumbent position for at least 20-minutes before testing began. Investigators conducted two 25-minute RMR measurements and discarded the data recorded during the first 5-minutes. A mean RMR value from the two measurements was computed for the data analysis. RMR was then calculated using eight common prediction equations (Table 1): Harris-Benedict [11], Robertson and Reid [12], Cunningham 1980 [19], FAO/WHO/UNU [13], Owen [17], Mifflin-St. Jeor [18], Cunningham 1991 [20], and Nelson [21].

\section{Statistical Analysis}

The Statistical Package for Social Sciences (SPSS), Version 21.0 (SPSS Institute, Chicago, IL) was used for all statistical analyses. Participants were grouped into 3 age groups, young $(20-30$ years $)$, midlife $(40-50$ years), and older ( $\geq 60$ years), based on self-reported age during the first study visit. Researchers completed separate analyses for each age category. Descriptive statistics (mean \pm standard deviation) were computed for age, height, weight, BMI, \% body fat, TSH, FSH, and measured RMR. One-way analysis of variance (ANOVA) using the post-hoc Bonferroni test explored the impact of age on the descriptive variables. A paired- samples $t$-test was conducted to compare measured RMR to predicted RMR for each of the eight prediction equations. Significance was defined as $p<$ 0.05 .

The limits identified by Bland and Altman [38] were applied to visually depict the most and least appropriate prediction equations for each age group. The appropriateness of each equation was identified by the extent of prediction bias, the mean difference (predicted RMR - measured RMR) for each equation. Bland-Altman plots displayed the calculated mean of predicted and measured RMR against the calculated difference between predicted and measured RMR for each study participant. The mean difference was defined by a solid horizontal line and the prediction bias was represented by the distance of the mean difference line from the zero difference point. Data points plotted closest to the zero difference point represent participants with a predicted RMR similar to the measured RMR. Two dashed lines, located two standard deviations (SD) above and below the mean difference line, correspond to the limits of agreement defined by Bland and Altman [38]. Prediction accuracy for each equation was defined as the percentage of women with a predicted RMR within $\pm 10 \%$ of 
measured RMR, a previously accepted error limit utilized by other investigators $[7,33]$. The percentage of women whose predicted RMR surpassed the limit of agreement, resulting in over or under-predictions, was also calculated for the eight equations and reported according to age category.

\section{RESULTS}

Of the initial 207 women who provided informed consent, 17 did not complete the RMR measurement, 12 were excluded due to occasional smoking, 16 were excluded due to a measured $\mathrm{BMI} \geq 30.0\left(\mathrm{~kg} / \mathrm{m}^{2}\right)$, and two had elevated serum TSH concentrations ( $>6.75$ $\mu \mathrm{lU} / \mathrm{mL}$ ). The present analysis includes data for 160 women (young, $\mathrm{n}=57$; midlife, $\mathrm{n}=57$; and older, $\mathrm{n}=46$ ).

Table 2 displays the descriptive characteristics of the participants. The mean age of the young, midlife, and older women was $25 \pm 3$ years, $44 \pm 3$ years, and $68 \pm 5$ years, respectively. For the older women, mean height $(161 \pm 6 \mathrm{~cm})$ was significantly lower than that of the young $(166 \pm 7 \mathrm{~cm})$ and midlife $(166 \pm 7 \mathrm{~cm})(p=$ $0.001)$ women. The older women had a greater BMI $\left(24.3 \pm 2.5 \mathrm{~kg} / \mathrm{m}^{2}\right)$ than that of the young women $(22.4$ $\left.\pm 2.7 \mathrm{~kg} / \mathrm{m}^{2}\right)(p=0.002)$. The mean FSH concentration of the older women $(69.9 \pm 28.0 \mathrm{IU} / \mathrm{L})$ was also significantly greater than that of the young $(6.2 \pm 2.5$ $\mathrm{IU} / \mathrm{L})$ and midlife women $(13.4 \pm 13.0 \mathrm{IU} / \mathrm{L})(p<0.001)$.
Mean body fat percent differed between all age categories (young $=29 \pm 9 \%$; midlife $=33 \pm 9 \%$; older $38 \pm 8 \%)(p<0.001)$, appearing lowest among the young women and highest among the older women.

The RMR values from the eight prediction equations and the measured RMR are shown in Table 3. The mean calculated difference (predicted RMR measured RMR) represents the bias between predicted RMR and measured RMR. For the young and midlife women, mean differences ranged from -50 and -38 (Nelson) to +211 and +213 (Cunningham 1980), respectively. The Owen equation provided RMR predictions that were closest to measured RMR for the younger $(+1)$ and midlife $(+35)$ women. For the older women, mean differences ranged from +27 (Nelson) to +281 (Cunningham 1980); the Nelson equation provided the least biased RMR predictions. The percentage of difference from measured RMR ranged from $+0.6 \%$ (Owen) to $+17.7 \%$ (Cunningham 1980) for the young women, $-2.8 \%$ (Nelson) to $+18.1 \%$ (Cunningham 1980) for the midlife women, and +2.8 (Nelson) to $+26.7 \%$ (Cunningham 1980) for the older women. The RMR estimate predicted from the Owen equation was not significantly different from measured RMR for young women $(p=0.905)$. In contrast, for the midlife women, all of the equations provided RMR predictions that were significantly different from measured values. For the older women, the Nelson

Table 2: Descriptive Characteristics of Young, Midlife, and Older Women ${ }^{a}$

\begin{tabular}{|c|c|c|c|c|c|c|c|}
\hline \multirow[b]{2}{*}{ Characteristics } & \multicolumn{2}{|c|}{$\begin{array}{l}\text { Young } \\
n=57\end{array}$} & \multicolumn{2}{|c|}{$\begin{array}{c}\text { Midlife } \\
n=57\end{array}$} & \multicolumn{2}{|c|}{$\begin{array}{l}\text { Older } \\
n=46\end{array}$} & \multirow[b]{2}{*}{$p$-value } \\
\hline & Mean $\pm S D^{b}$ & Range $^{c}$ & Mean $\pm S D^{b}$ & Range $^{c}$ & Mean $\pm S D^{b}$ & Range $^{c}$ & \\
\hline Age (y) & $25 \pm 3$ & $20-30$ & $44 \pm 3$ & $40-50$ & $68 \pm 5$ & $60-77$ & --- \\
\hline Height (cm) & $166 \pm 7^{\#}$ & $151-177$ & $166 \pm 7^{\#}$ & $151-182$ & $161 \pm 6^{\S}$ & $150-174$ & $0.001^{*}$ \\
\hline Weight (kg) & $61 \pm 9$ & $41-79$ & $64 \pm 7$ & $52-88$ & $63 \pm 8$ & $46-84$ & 0.254 \\
\hline BMI $\left(\mathrm{kg} / \mathrm{m}^{2}\right)^{d}$ & $22.4 \pm 2.7^{\#}$ & $17.3-29.6$ & $23.2 \pm 2.6$ & $18.5-29.5$ & $24.3 \pm 2.5^{\S}$ & $19.0-29.3$ & $0.002^{*}$ \\
\hline Body Fat $(\%)^{\mathrm{e}}$ & $29 \pm 9^{\#}$ & $8-50$ & $33 \pm 9^{\S}$ & $16-52$ & $38 \pm 8^{*}$ & $10-60$ & $<0.001^{*}$ \\
\hline TSH $(\mu \mathrm{IU} / \mathrm{mL})^{f}$ & $2.2 \pm 1.2$ & $0.3-6.0$ & $2.2 \pm 1.1$ & $0.0-5.8$ & $2.6 \pm 1.7$ & $0.0-6.7$ & 0.259 \\
\hline $\mathrm{FSH}(\mathrm{IU} / \mathrm{L})^{\mathrm{g}, \mathrm{h}}$ & $6.2 \pm 2.5^{\#}$ & $0.2-11.2$ & $13.4 \pm 13.0^{\#}$ & $1.3-62.1$ & $69.9 \pm 28.0^{\S}$ & $14.9-127.7$ & $<0.001^{*}$ \\
\hline Measured RMR & $1234 \pm 118^{\#}$ & $945-1520$ & $1218 \pm 117^{\#}$ & $985-1500$ & $1080 \pm 111^{\S}$ & $825-1455$ & $<0.001^{*}$ \\
\hline
\end{tabular}

${ }^{a}$ Means with different superscripts are significantly different from one another $(p<0.05)$.

${ }^{\mathrm{b}} \mathrm{SD}=$ standard deviation.

${ }^{\mathrm{C}}$ Range $=$ minimum - maximum

${ }^{\mathrm{d}} \mathrm{BMI}=$ body mass index.

${ }^{\mathrm{e}}$ Three young participants did not complete DXA assessment; mean and standard deviation include 54 young participants.

${ }^{\mathrm{f}} \mathrm{TSH}=$ thyroid stimulating hormone.

${ }^{9} \mathrm{FSH}=$ follicle stimulating hormone

${ }^{\mathrm{h}}$ One young participant did not complete the FSH assessment; mean and standard deviation reflect 56 young participants.

'RMR = resting metabolic rate

${ }^{*} p<0.05$ 


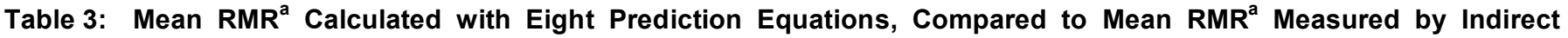
Calorimetry (IC)

\begin{tabular}{|c|c|c|c|c|c|}
\hline & $\mathrm{RMR}^{\mathrm{a}, \mathrm{b}}$ & $\begin{array}{l}\text { Difference (kcal) } \\
\left(\text { Predicted RMR }^{\mathrm{a}}-\right. \\
\text { Measured } \mathrm{RMR}^{\mathrm{a}} \text { ) }\end{array}$ & $\begin{array}{c}\text { Percentage of Difference } \\
\text { (Difference/Measured RMR }{ }^{\mathrm{a}} \mathrm{x} \\
100 \%)\end{array}$ & t-statistic & p-value \\
\hline Young & $1234 \pm 118$ & --- & --- & --- & --- \\
\hline Midlife & $1218 \pm 117$ & --- & --- & --- & --- \\
\hline \multicolumn{6}{|l|}{ Harris-Benedict } \\
\hline Young & $1430 \pm 92$ & +196 & $16.4 \%$ & 20.7 & $<0.001^{*}$ \\
\hline Midlife & $1363 \pm 77$ & +146 & $12.6 \%$ & 11.2 & $<0.001^{*}$ \\
\hline Older & $1236 \pm 89$ & +155 & $15.0 \%$ & 12.2 & $<0.001^{*}$ \\
\hline Older & $1236 \pm 91$ & +156 & $15.0 \%$ & 12.9 & $<0.001^{*}$ \\
\hline \multicolumn{6}{|l|}{ Cunningham 1980} \\
\hline Young & $1446 \pm 111$ & +211 & $17.7 \%$ & 14.1 & $<0.001^{*}$ \\
\hline Midlife & $1431 \pm 116$ & +213 & $18.1 \%$ & 13.4 & $<0.001^{*}$ \\
\hline Older & $1362 \pm 106$ & +281 & $26.7 \%$ & 20.6 & $<0.001^{*}$ \\
\hline \multicolumn{6}{|l|}{ FAO/WHO/UNU } \\
\hline Young & $1403 \pm 133$ & +169 & $14.0 \%$ & 15.5 & $<0.001^{*}$ \\
\hline Midlife & $1378 \pm 61$ & +160 & $13.9 \%$ & 11.7 & $<0.001^{*}$ \\
\hline \multicolumn{6}{|l|}{ Mifflin-St. Jeor } \\
\hline Young & $1363 \pm 117$ & +129 & $10.7 \%$ & 12.6 & $<0.001^{*}$ \\
\hline Midlife & $1292 \pm 99$ & +74 & $6.6 \%$ & 5.6 & $<0.001^{*}$ \\
\hline Older & $1140 \pm 110$ & +60 & $5.9 \%$ & 4.5 & $<0.001^{*}$ \\
\hline \multicolumn{6}{|l|}{ Cunningham 1991} \\
\hline Young & $1299 \pm 109$ & +63 & $5.7 \%$ & 4.3 & $<0.001^{*}$ \\
\hline Midlife & $1284 \pm 114$ & +66 & $6.0 \%$ & 4.2 & $<0.001^{*}$ \\
\hline Older & $1216 \pm 104$ & +136 & $13.1 \%$ & 10.0 & $<0.001^{*}$ \\
\hline \multicolumn{6}{|l|}{ Nelson et al. } \\
\hline Young & $1185 \pm 134$ & -50 & $-3.9 \%$ & -3.5 & $0.001^{*}$ \\
\hline Midlife & $1180 \pm 128$ & -38 & $-2.8 \%$ & -2.4 & $0.020^{*}$ \\
\hline Older & $1108 \pm 125$ & +27 & $2.8 \%$ & 2.0 & 0.051 \\
\hline
\end{tabular}

${ }^{\mathrm{a}} \mathrm{RMR}=$ resting metabolic rate; expressed in kcal.

${ }^{b}$ Expressed as mean \pm standard deviation.

${ }^{*} \mathrm{p}<0.05$. 
equation was the only equation that was not significantly different from measured RMR $(p=0.051)$.

Bland-Altman plots were included for the equations providing the least and greatest mean prediction bias
(Figures 1-6). The Owen equation provided the least biased RMR predictions for the young (Figure 1) and midlife women (Figure 2), indicated by the close proximity of the solid mean difference line to the zerodifference point on the y-axis. Similarly, the Nelson

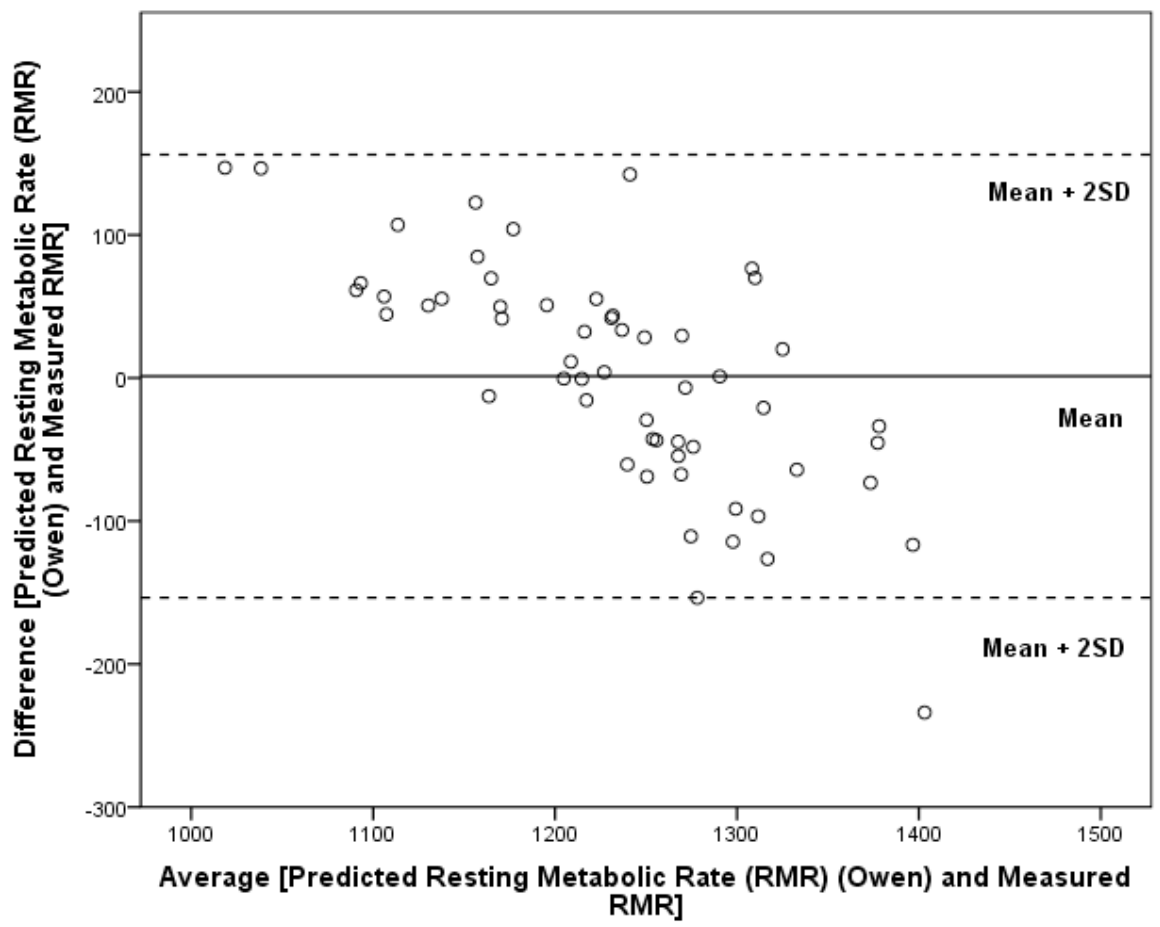

Figure 1: Bland-Altman plot: Mean bias and distribution of resting metabolic rate (RMR) prediction with the Owen equation for 57 young women.

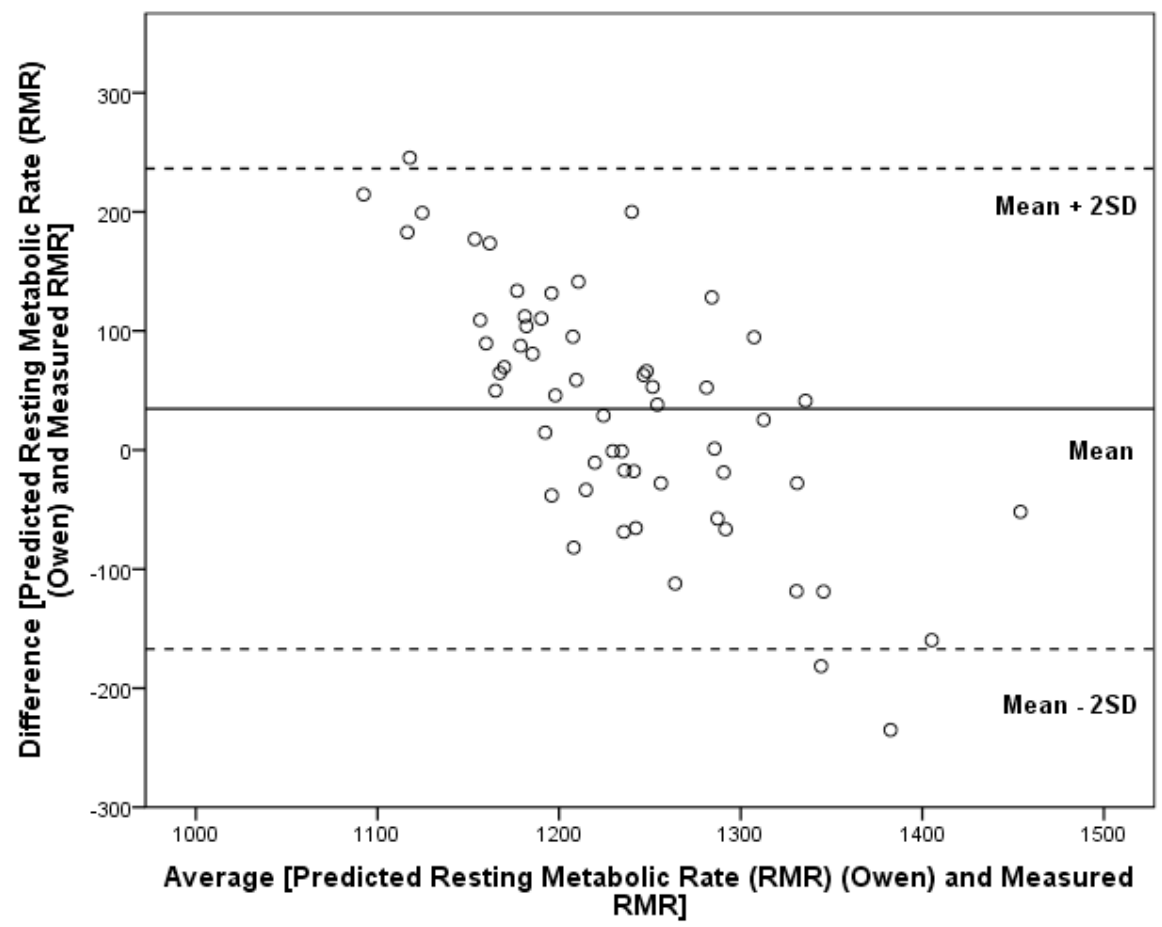

Figure 2: Bland-Altman plot: Mean bias and distribution of resting metabolic rate (RMR) prediction with the Owen equation for 57 midlife women. 


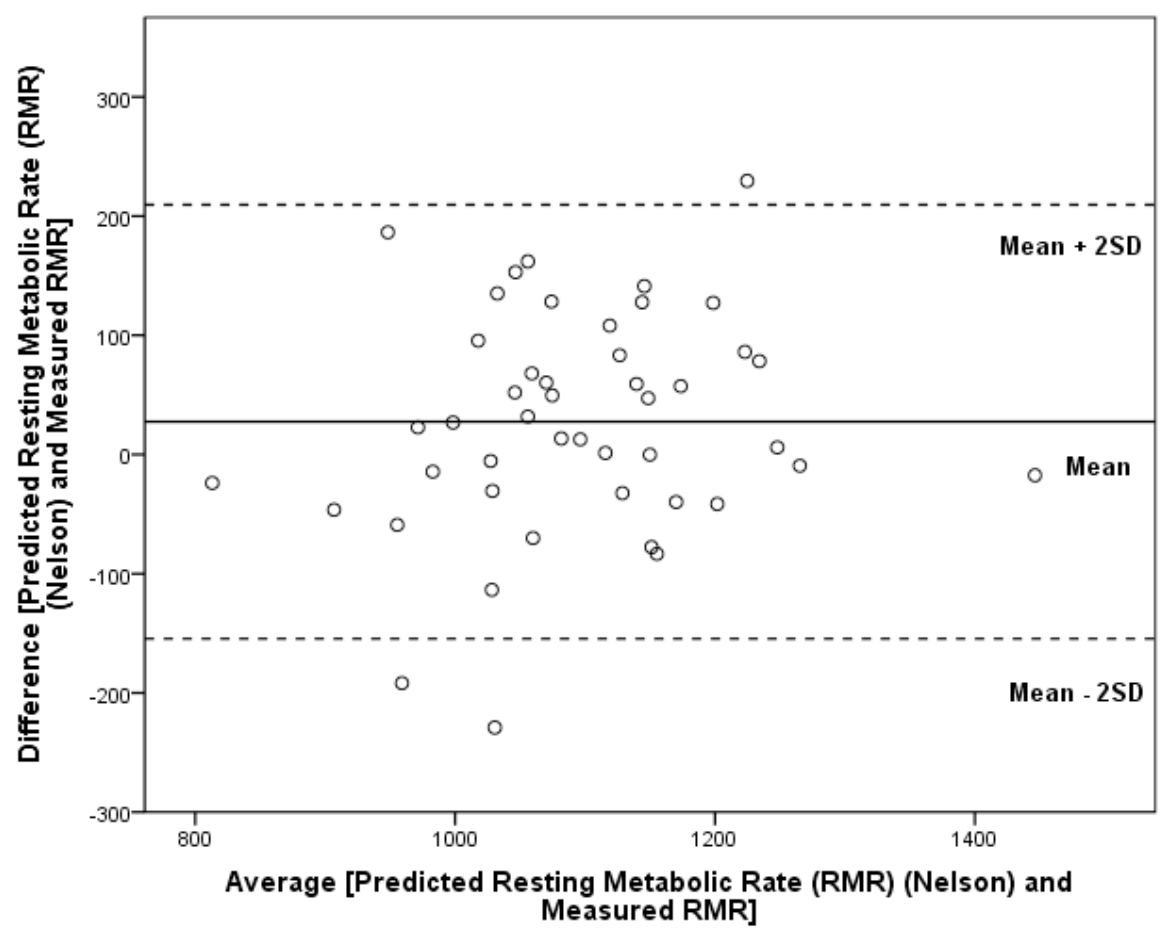

Figure 3: Bland-Altman plot: Mean bias and distribution of resting metabolic rate (RMR) prediction with the Nelson equation for 46 older women.

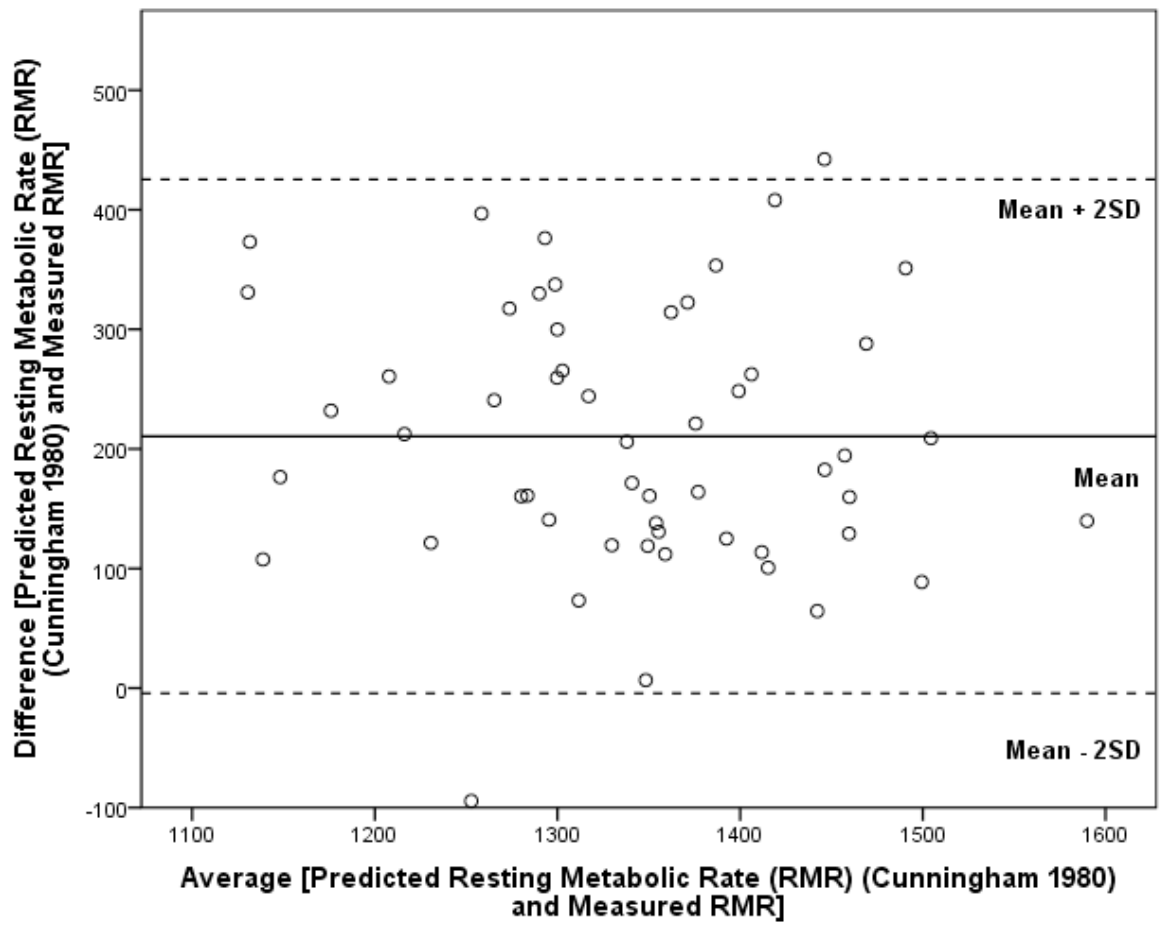

Figure 4: Bland-Altman plot: Mean bias and distribution of resting metabolic rate (RMR) prediction with the Cunningham 1980 equation for 54 young women.

equation provided the least biased RMR predictions for the older women (Figure 3). The Cunningham 1980 equation resulted in the greatest mean prediction bias for all age categories (Figures 4-6).
Table 4 depicts the results of prediction accuracy assessments conducted for each equation according to the RMR predictions for each age group. The Owen equation provided the best prediction accuracy for the 


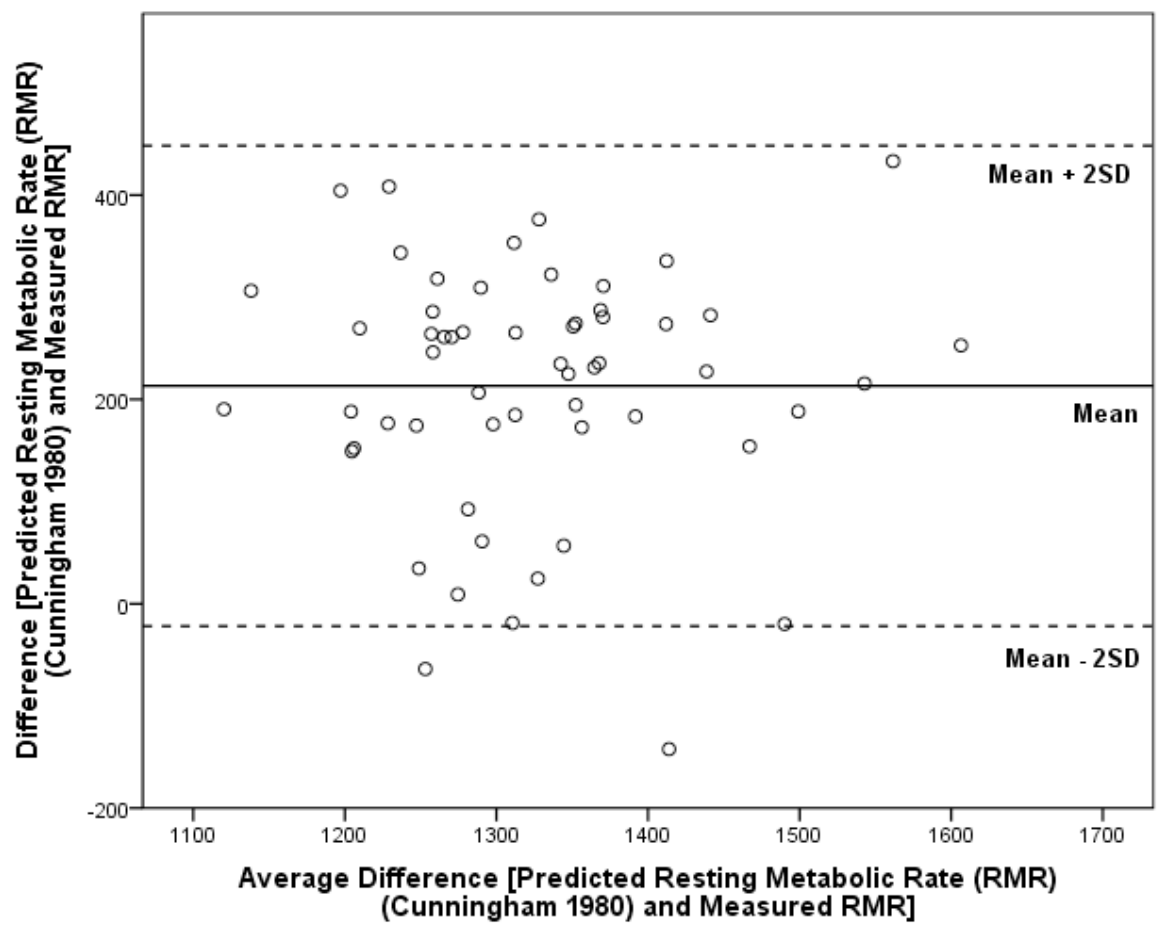

Figure 5: Bland-Altman plot: Mean bias and distribution of resting metabolic rate (RMR) prediction with the Cunningham 1980 equation for 57 midlife women.

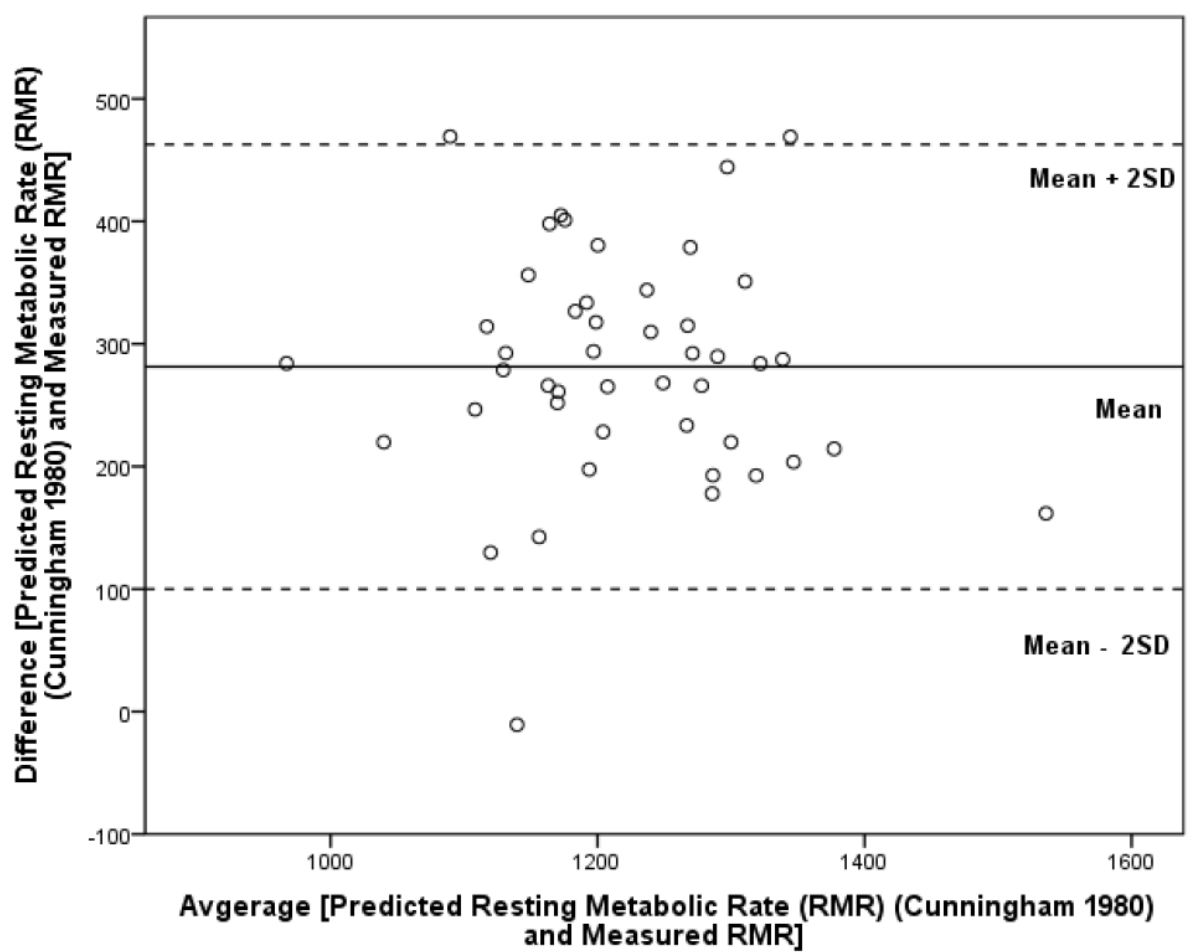

Figure 6: Bland-Altman plot: Mean bias and distribution of resting metabolic rate (RMR) prediction with the Cunningham 1980 equation for 46 older women.

young women $(87.7 \%)$. For the midlife women, the Owen and Nelson equations had the greatest prediction accuracy $(75.4 \%$ for both equations). The Nelson equation also provided the most accurate RMR prediction among the older women $(71.7 \%)$. The Cunningham 1980 equation most frequently overpredicted RMR for the midlife $(82.5 \%)$ and older women $(97.8 \%)$, while the Harris-Benedict equation 
Table 4: Assessment of Prediction Accuracy for each Age Group in Comparison to Measured RMR ${ }^{\mathrm{a}}$ by Indirect Calorimetry, Using the Commonly Accepted Error Limit of $\pm 10 \%$ of Measured RMR $^{\mathrm{a}}$

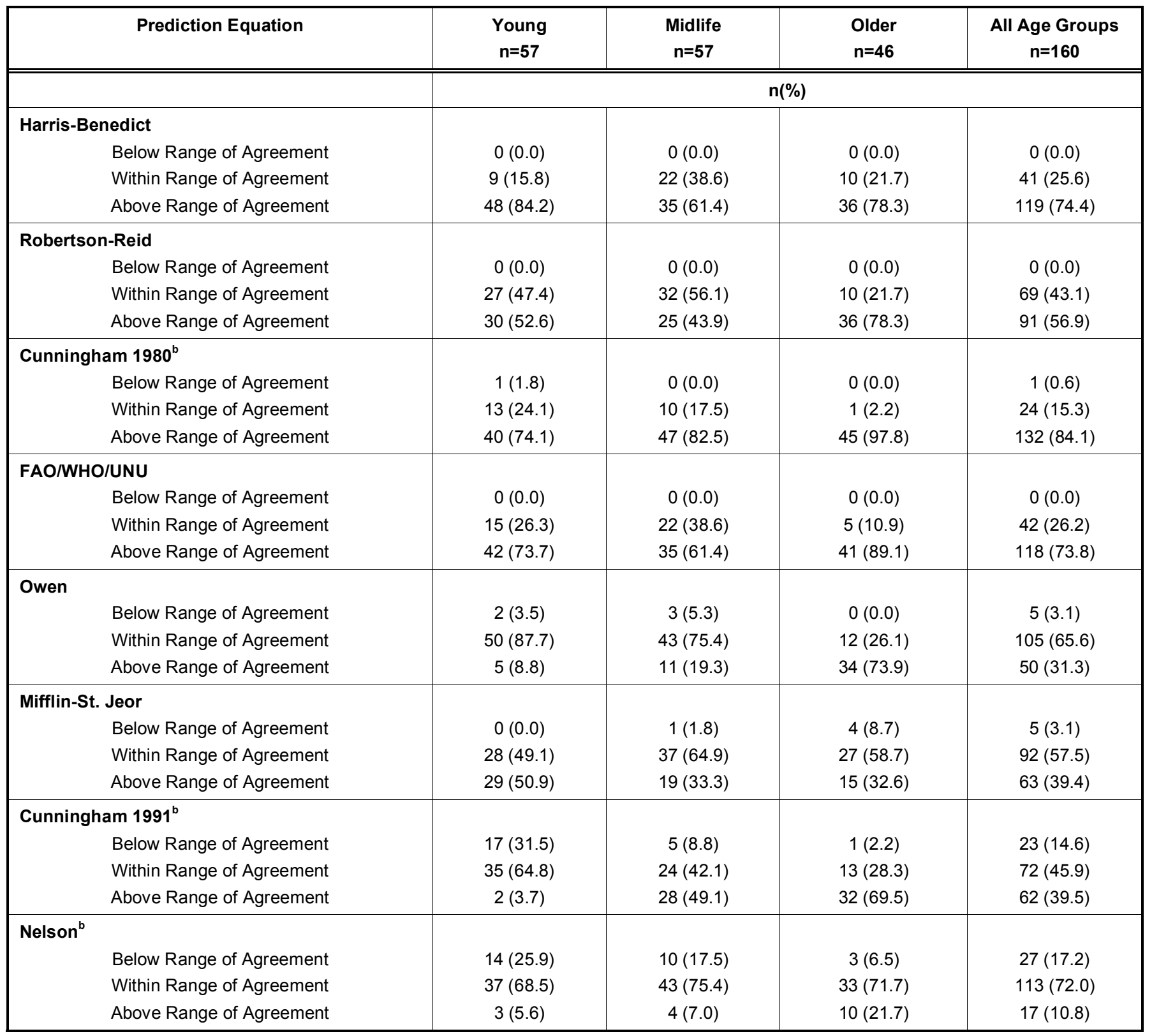

${ }^{\mathrm{a}} \mathrm{RMR}=$ resting metabolic rate.

${ }^{\mathrm{b}}$ Three young participants did not complete DXA assessment; therefore prediction equations using body composition measures could not be completed.

most frequently over-predicted RMR among the young women $(84.2 \%)$. With the exception of two equations (Cunningham 1991 and Nelson for the young and midlife women, respectively), over-predictions were more common than under-predictions for all equations, among the age groups.

\section{DISCUSSION}

This study found that accuracy of RMR prediction equations differed by age. The Owen and Nelson equations predicted RMR with the least bias and greatest accuracy for the young and older women, respectively. For the midlife women, all equations significantly overestimated RMR in comparison to the measured RMR, except the Nelson equation, which under-estimated RMR.

Three of the prediction equations examined in this study incorporate body composition as part of the equation (Cunningham 1980 [19], Cunningham 1991 [20], and Nelson [21]). One of these equations, the Nelson equation, provided the highest prediction accuracy for all age groups. The Nelson equation 
incorporates both FFM and FM in the RMR estimation. Although FFM is considered the most metabolically active tissue in the body, recent research suggests that the metabolic rate of adipose tissue is higher in women than men [39]. When the Nelson, Cunningham 1980 and Cunningham 1991 equations were developed, different methodology was used to assess body composition. For example, the Cunningham 1980 equation incorporated the Moore equation [40] (based on weight and age) to estimate the LBM of participants. In contrast, body composition for the Cunningham 1991 and Nelson equations was measured via densitometry, anthropometry, and total body potassium. In the current study, body composition was assessed using DXA and may have provided results similar to the more recently developed RMR prediction equations [20,21]. Advances in body composition methodologies [41] may continue to influence the accuracy of body composition-dependent RMR prediction equations.

For the younger women in the current study, the Owen equation provided the greatest RMR prediction accuracy (Table 4). The accuracy of a prediction equation may be impacted when the descriptive characteristics (i.e., sex, age, weight, height, body composition, physical activity level) of the participants included in the derivation of the prediction equation differ from the population under study. Approximately $40 \%$ of the non-athletic participants included in the development of the Owen equation were between 20 and 30 years old [17]. Unfortunately, body composition of these young women was not reported. Despite the inclusion of young women in the original HarrisBenedict sample [11], the Harris-Benedict equation overestimated RMR for $84.2 \%$ of the young women in the current study. The descriptive characteristics of the young individuals included in the development of this RMR prediction equation may not have appropriately represented those of the young participants in the current study.

RMR validation studies with young participants have also found that the accuracy of RMR prediction equations varies [27,28,42]. For instance, Garrel et al. [42] examined the accuracy of seven equations among 28 normal-weight women (mean age $=23 \pm 3$ years). Similar to results of the current study, the Owen equation predicted RMR within $10 \%$ of measured RMR for approximately $80 \%$ of the women and the HarrisBenedict equation over-predicted RMR for the majority of the women [42]. In contrast, Garrel et al. [42] reported that predictions from the $\mathrm{FAO} / \mathrm{WHO} / \mathrm{UNU}$ equation were within $10 \%$ of measured values for all study participants. In another RMR validation study with young women, Siervo et al. [28] included 157 normal weight, overweight, and obese women aged 18 - 35 years (mean age $=24 \pm 4,25 \pm 5$, and $24 \pm 5$ years, respectively). For the normal weight women, the Owen equation provided the most accurate RMR predictions. However, for the overweight women, another equation, the Bernstein equation, was most accurate [28]. Similar to the current study, Siervo et al. [28] found the Harris-Benedict and FAO/WHO/UNU equations over-predicted RMR for normal weight and overweight women. A more recent study [27] examined the accuracy of RMR equations among healthy young female college students aged $20-33$ years (mean age $=22 \pm 3$ years; mean BMI $=21.8 \pm 2.1 \mathrm{~kg} / \mathrm{m}^{2}$ ) and reported that six RMR prediction equations overpredicted RMR $(p<0.001)$. The consistent overpredictions may be attributed to the relatively low measured RMR values of the sample (mean RMR measured by IC = $1027 \pm 171 \mathrm{kcal}$ ). The researchers reported that the Nelson and Owen equations provided RMR predictions with the lowest mean difference from measured values, while the Harris-Benedict equation produced the greatest over-prediction [27]. In the current study, the Owen and Nelson equations did not regularly over-predict RMR and the mean measured RMR of the young women was $1234 \pm 118 \mathrm{kcal}$. Thus, research to date seems to consistently support the use of the Owen and Nelson RMR prediction equations for young women.

For the midlife women in the current study, the Owen and Nelson equations provided the most accurate RMR predictions (Table 4). However, all of the RMR estimates from the prediction equations were significantly different from measured RMR (Table 3 ). Although the midlife women reported regular menstruation, the FSH concentrations of this group varied from 1.3 to $62.1 \mathrm{IU} / \mathrm{L}$ (Table 2), suggesting heterogeneity of the perimenopausal state within this age group. This observation is notable because body composition and resting metabolic rate changes occur during the perimenopause stage of life $[43,44]$. Unfortunately, none of the prediction equations evaluated in this study reported FSH concentrations for the midlife women included in the derivation of the equation.

To our knowledge, few studies have evaluated the accuracy of RMR predictions for healthy midlife women. A small validation study conducted by Santos et al. [34] included 46 climacteric women in Brazil aged $42-73$ years (mean age $=55$ years) and observed 
poor correlations between prediction equations, such as the Harris Benedict, to measured RMR by IC. In this study, the FAO/WHO/UNU equation predicted RMR with the highest concordance coefficient (concordance coefficient $=0.63$ ). Because the participants represented a wide age range, the results may have differed if the analyses were limited to midlife women aged 40 - 50 years, such as in the current study. Identifying the best RMR prediction equation remains a challenge for midlife women due to the physiological and hormonal changes that accompany the perimenopausal state. Thus, more research is needed to determine the most appropriate RMR prediction equation for this age group of women.

Among the older women in the current study, six of the eight equations over-predicted RMR. This finding may be partially explained by the limited representation of older women in the study samples used in the derivation of the prediction equations. For example, the Owen equation included just one female participant over the age of 59 [17] and the original Harris-Benedict equation only included six older female participants [11]. Similarly, only nine older participants were included when developing the Cunningham 1980 prediction equation, representing approximately $4 \%$ of the total sample [19]. Furthermore, the FAO/WHO/UNU prediction equations were developed using part of a database complied by Schofield et al. [14,15]. However, only one small study aside from the HarrisBenedict study included older women, indicating that this age group was under-represented in the complete database. The Nelson equation may have resulted in the most accurate RMR predictions due to the incorporation of both FFM and FM in the calculation [21]. Since relative FFM decreases and FM increases with age [45], accounting for the metabolic activity of both tissue types may have resulted in improved prediction accuracy for this age group.

Results of prior validation studies among older adults have illustrated the limited applicability of most RMR prediction equations for this age group [29,3133]. Arciero et al. [29] measured RMR, body composition, physical activity, and dietary intakes in a cohort of 75 women aged 50 to 81 (mean age $=61 \pm 8$ years). Researchers [29] observed that the FAO/WHO/UNU for women $>60$ years $(p=0.12)$ and Harris-Benedict $(p=0.07)$ equations predicted RMR similar to measured RMR; however, the Mifflin-St. Jeor $(p<0.01)$ and Owen $(p<0.01)$ equations significantly under-predicted RMR for this group of women. In contrast, Taaffe et al. [32] reported that the Owen and
Harris-Benedict equations predicted RMR closest to measured RMR among 116 healthy older white women aged $60-82$ years (mean age $=67 \pm 4$ years). Similar to the current study, Taaffe et al. [32] reported that the Cunningham 1980 equation resulted in the largest prediction error of the eight equations evaluated in the study. The largest validation study conducted with older adults was completed by Luhrmann et al. [31] and included 130 men and 225 women aged $60-85$ years (mean age of women $=68 \pm 6$ years). As observed in the current study, Luhrmann et al. [31] reported that the FAO/WHO/UNU significantly over-predicted RMR in normal and overweight older women. In contrast, the Harris-Benedict equation significantly under-predicted RMR for these older women [31]. The underpredictions reported by Lurhmann et al. [31] may have occurred among participants who smoked. More recently, Melzer et al. [33] evaluated the prediction accuracy of five RMR equations in 119 healthy older adults (including 55 women) aged $70-98$ years (mean age of women $=78.6 \pm 5.3$ years). For the women in this study [33], only the Owen and Luhrmann equations, a more recently introduced prediction equation, did not differ significantly from measured RMR. However, on an individual basis, the HarrisBenedict, Luhrmann, and Owen equations predicted RMR within $10 \%$ of measured RMR for $74.5 \%$ of the female participants [33]. The rate of progressive agerelated changes in RMR due to factors, such as FFM loss, decline in organ weight, and tissue and organ cell loss $[33,45]$ may vary on an individual basis, making older adults a relatively heterogeneous group. Additionally, the extent of these physiologic changes becomes more pronounced among individuals in the oldest-old age category in comparison to younger, older adults. Results of Melzer et al. [33] may have differed from the current study (mean age $=68 \pm 5$, range $=60-77$ years) due to the inclusion of older participants. As indicated by the variable results of previous validation studies conducted with older women, predicting RMR of older women with equations developed from younger age groups may impact the results. The most appropriate RMR prediction equation for older women remains unknown. Since FFM commonly declines with age, RMR prediction equations that include anthropometric measurements seem best to use with older women.

To our knowledge, this study is the first to provide a comprehensive evaluation of eight RMR prediction equations with healthy, non-obese, free-living women representing three distinct age categories (young $=20$ 
- 30 years, midlife $=40-50$ years, and older $=\geq 60$ years). Strengths of the study include the methodology with the body composition measurements completed by DXA and RMR measurements completed by indirect calorimetry. The protocol recommended by the Academy of Nutrition and Dietetics Evidence Analysis Working Group was followed for measuring RMR. Participants were also excluded from the study if they reported smoking or had abnormal thyroid hormone concentrations, confirmed by a fasting blood draw. This study is limited by the heterogeneous perimenopausal status of the midlife women. Only eight RMR prediction equations were evaluated. Since this study was limited to normal and over-weight women, results are not generalizable to men or women with a BMI $>30 \mathrm{~kg} / \mathrm{m}^{2}$.

\section{CONCLUSION}

The current study evaluated the applicability of eight RMR prediction equations among a sample of young, midlife, and older non-obese women. The Owen and Nelson equations predicted RMR similar to measured RMR by IC for young and older women, respectively and may provide nutrition practitioners with the most accurate RMR prediction for these populations. In contrast, for midlife women, none of the equations predicted RMR similar to the measured value. For all age groups, the use of an appropriate RMR prediction equation is invaluable to Registered Dietitian Nutritionists and nutrition clinicians to determine an appropriate nutrition care plan and monitor patient care. Future studies should include larger samples of women, categorized by menstrual status rather than age. Additional research is necessary to evaluate the appropriateness of body composition-specific RMR prediction equations and optimize RMR prediction of women across the lifespan.

\section{NOTE}

At the time of the study, C Reese, L Beaird, and $M$ Mason were students at Arizona State University and $S$ Miller was a student at New York University.

\section{REFERENCES}

[1] Ross AC, Caballero B, Cousins RJ, Tucker KL, Ziegler TR. Modern Nutrition in Health and Disease. 11th ed. Philadelphia, PA: Lippincott Williams \& Wilkins 2012; p. 1648.

[2] Bogardus C, Lillioja S, Ravussin E, Abbott W, Zawadzki JK, Young $A$, et al. Familial dependence of the resting metabolic rate. N Engl J Med 1986; 315: 96-100. http://dx.doi.org/10.1056/NEJM198607103150205

[3] Freni SC, Lewis SM, Mayhugh MA, Jairaj K, Arani RB, Turturro $\mathrm{A}$, et al. Improved equations for estimating the resting metabolic rate. Hum Ecol Risk Assess 2000; 6: 103954.

\section{http://dx.doi.org/10.1080/10807030091124275}

[4] Harris JA, Benedict FG. A biometric study of human basal metabolism. Proc Natl Acad Sci USA 1918; 4: 370-3.

http://dx.doi.org/10.1073/pnas.4.12.370

[5] Bisdee JT, James WP, Shaw MA. Changes in energy expenditure during the menstrual cycle. Br J Nutr 1989; 61: 187-99.

http://dx.doi.org/10.1079/BJN19890108

[6] Koot $P$, Deurenberg P. Comparison of changes in energy expenditure and body temperatures after caffeine consumption. Ann Nutr Metab 1995; 39: 135-42. http://dx.doi.org/10.1159/000177854

[7] Frankenfield D, Roth-Yousey L, Compher C. Comparison of predictive equations for resting metabolic rate in healthy nonobese and obese adults: a systematic review. J Am Diet Assoc 2005; 105: 775-89. http://dx.doi.org/10.1016/j.jada.2005.02.005

[8] Frankenfield D, Hise M, Malone A, Russell M, Gradwell E, Compher $\mathrm{C}$, et al. Prediction of resting metabolic rate in critically ill adult patients: results of a systematic review of the evidence. J Am Diet Assoc 2007; 107: 1552-61. http://dx.doi.org/10.1016/j.jada.2007.06.010

[9] Holdy KE. Monitoring energy metabolism with indirect calorimetry: instruments, interpretation, and clinical application. Nutr Clin Pract 2004; 19: 447-54. http://dx.doi.org/10.1177/0115426504019005447

[10] McClave SA, Snider HL, Ireton-Jones C. Can we justify continued interest in indirect calorimetry? Nutr Clin Pract 2002; 17: 133-6.

http://dx.doi.org/10.1177/0115426502017003133

[11] Harris JA, Benedict FG. A biometric study of basal metabolism in man. Washington DC: Washington Carnegie Institution of Washington 1919; p. 284.

[12] Robertson JD, Reid DD. Standards for the basal metabolism of normal people in Britain. Lancet 1952; 1(6715): 940-3. http://dx.doi.org/10.1016/S0140-6736(52)90543-6

[13] Food and Agricultural Organization/World Health Organization/United Nations University. Energy and Protein Requirements. Geneva, Switzerland: World Health Organization; 1985.

[14] Schofield C. An annotated bibliography of source material for basal metabolic rate data. Hum Nutr Clin Nutr 1985; 39(Suppl 1): 42-91.

[15] Schofield WN. Predicting basal metabolic rate, new standards and review of previous work. Hum Nutr Clin Nutr 1985; 39(Suppl 1): 5-41.

[16] Owen OE, Holup JL, Owen OE, Holup JL, D'Alessio DA, Craig ES, et al. A reappraisal of the caloric requirements of men. Am J Clin Nutr 1987; 46: 875-85.

[17] Owen OE, Kavle E, Owen RS, Polansky M, Caprio S, Mozzoli MA, et al. A reappraisal of caloric requirements in healthy women. Am J Clin Nutr 1986; 44: 1-19.

[18] Mifflin MD, St Jeor ST, Hill LA, Scott BJ, Daugherty SA, Koh $Y O$. A new predictive equation for resting energy expenditure in healthy individuals. Am J Clin Nutr 1990; 51: 241-7.

[19] Cunningham JJ. A reanalysis of the factors influencing basal metabolic rate in normal adults. Am J Clin Nutr 1980; 33: 2372-4.

[20] Cunningham JJ. Body composition as a determinant of energy expenditure: a synthetic review and a proposed general prediction equation. Am J Clin Nutr 1991; 54: 963-9.

[21] Nelson KM, Weinsier RL, Long CL, Schutz Y. Prediction of resting energy expenditure from fat-free mass and fat mass. Am J Clin Nutr 1992; 56: 848-56.

[22] Ravussin E, Burnand B, Schutz $Y$, Jéquier E. Twenty-fourhour energy expenditure and resting metabolic rate in obese, 
moderately obese, and control subjects. Am J Clin Nutr 1982; 35: 566-73.

[23] Den Besten C, Vansant G, Weststrate JA, Deurenberg P. Resting metabolic rate and diet-induced thermogenesis in abdominal and gluteal-femoral obese women before and after weight reduction. Am J Clin Nutr 1988; 47: 840-7.

[24] Bessard T, Schutz Y, Jéquier E. Energy expenditure and postprandial thermogenesis in obese women before and after weight loss. Am J Clin Nutr 1983; 38: 680-93.

[25] Ravussin E, Burnand B, Schutz Y, Jéquier E. Energy expenditure before and during energy restriction in obese patients. Am J Clin Nutr 1985; 41: 753-9.

[26] Weststrate JA, Weys PJ, Poortvliet EJ, Deurenberg P, Hautvast JG. Diurnal variation in postabsorptive resting metabolic rate and diet-induced thermogenesis. Am J Clin Nutr 1989; 50: 908-14.

[27] Li AC, Tereszkowski CM, Edwards AM, Simpson JA, Buchholz AC. Published predictive equations overestimate measured resting metabolic rate in young, healthy females. $J$ Am Coll Nutr 2010; 29: 222-7.

http://dx.doi.org/10.1080/07315724.2010.10719837

[28] Siervo M, Boschi V, Falconi C. Which REE prediction equation should we use in normal-weight, overweight and obese women? Clin Nutr 2003; 22: 193-204. http://dx.doi.org/10.1054/clnu.2002.0625

[29] Arciero PJ, Goran MI, Gardner AM, Ades PA, Tyzbir RS, Poehlman ET. A practical equation to predict resting metabolic rate in older females. J Am Geriatr Soc 1993; 41: 389-95.

http://dx.doi.org/10.1111/j.1532-5415.1993.tb06946.x

[30] Lührmann PM, Herbert BM, Krems C, Neuhäuser-Berthold M. A new equation especially developed for predicting resting metabolic rate in the elderly for easy use in practice. Eur J Nutr 2002; 41: 108-13.

http://dx.doi.org/10.1007/s003940200016

[31] Lührmann PM, Neuhäeuser Berthold M. Are the equations published in literature for predicting resting metabolic rate accurate for use in the elderly? J Nutr Health Aging 2004; 8: 144-9.

[32] Taaffe DR, Thompson J, Butterfield G, Marcus R. Accuracy of Equations to Predict Basal Metabolic Rate in Older Women. J Am Diet Assoc 1995; 95: 1387-92. http://dx.doi.org/10.1016/S0002-8223(95)00366-5

[33] Melzer K, Laurie Karsegar V, Genton L, Kossovsky MP, Kayser B, Pichard C. Comparison of equations for estimating resting metabolic rate in healthy subjects over 70 years of age. Clin Nutr 2007; 26: 498-505. http://dx.doi.org/10.1016/j.clnu.2007.05.002

[34] Santos RD, Suen VM, Marchini JS, lannetta O. What is the best equation to estimate the basal energy expenditure of climacteric women? Climacteric 2011; 14: 112-6. http://dx.doi.org/10.3109/13697137.2010.527024
[35] Compher C, Frankenfield D, Keim N, Roth-Yousey L, Evidence Analysis Working Group. Best Practice Methods to Apply to Measurement of Resting Metabolic Rate in Adults: A Systematic Review. J Am Diet Assoc 2006; 106: 881-903. http://dx.doi.org/10.1016/j.jada.2006.02.009

[36] Collins LC, Cornelius MF, Vogel RL, Walker JF, Stamford BA. Effect of caffeine and/or cigarette smoking on resting energy expenditure. Int J Obes Relat Metab Disord 1994; 18: 551-6.

[37] Chad KE, Wenger HA. The effect of exercise duration on the exercise and post-exercise oxygen consumption. Can $\mathrm{J}$ Sport Sci 1988; 13: 204-7.

[38] Bland JM, Altman DG. Statistical methods for assessing agreement between two methods of clinical measurement. Lancet 1986; 1(8476): 307-10. http://dx.doi.org/10.1016/S0140-6736(86)90837-8

[39] Nookaew I, Svensson P-AA, Jacobson P, Jernås M, Taube $\mathrm{M}$, Larsson I, et al. Adipose tissue resting energy expenditure and expression of genes involved in mitochondrial function are higher in women than in men. J Clin Endocrinol Metab 2013; 98: E370-8.

http://dx.doi.org/10.1210/jc.2012-2764

[40] Moore F, Olesen K, McMurray J, Parker V, Ball M, Boyden C. The body cell mass and its supporting environment. Philadelphia, PA: WB Saunders Company; 1963.

[41] Fosbøl MØ, Zerahn B. Contemporary methods of body composition measurement. Clin Physiol Funct Imaging 2015; 35: 81-97.

http://dx.doi.org/10.1111/cpf.12152

[42] Garrel DR, Jobin N, de Jonge LH. Should we still use the Harris and Benedict equations? Nutr Clin Pract 1996; 11: 99103. http://dx.doi.org/10.1177/011542659601100399

[43] Wang Q, Hassager C, Ravn P, Wang S, Christiansen C. Total and regional body-composition changes in early postmenopausal women: age-related or menopause-related? Am J Clin Nutr 1994; 60: 843-8.

[44] Heymsfield SB, Gallagher D, Poehlman ET, Wolper C Nonas K, Nelson D, et al. Menopausal changes in body composition and energy expenditure. Exp Gerontol 1994; 29:377-89. http://dx.doi.org/10.1016/0531-5565(94)90018-3

[45] Krems C, Lührmann PM, Strassburg A, Hartmann B Neuhäuser-Berthold $M$. Lower resting metabolic rate in the elderly may not be entirely due to changes in body composition. Eur J Clin Nutr 2005; 59: 255-62. http://dx.doi.org/10.1038/sj.ejcn.1602066

[46] Dubois D, DuBois EF. A formula to estimate the approximate surface area if height and weight be known. Arch Int Med 1916; 17: 863-71.

http://dx.doi.org/10.1001/archinte.1916.00080130010002

\section{DOI: http://dx.doi.org/10.6000/1929-5634.2015.04.02.3}

(c) 2015 Woolf et al.; Licensee Lifescience Global.

This is an open access article licensed under the terms of the Creative Commons Attribution Non-Commercial License (http://creativecommons.org/licenses/by-nc/3.0/) which permits unrestricted, non-commercial use, distribution and reproduction in any medium, provided the work is properly cited. 